\title{
Serbska dominacja polityczna w pierwszej federacji narodów południowosłowiańskich (1918-1941) - zarys problematyki
}

Zarys treści: W artykule przedstawiono zarys serbskiej dominacji politycznej w federacji narodów południowosłowiańskich z lat 1918-1941. W pierwszej części przywołano kwestie związane z aktywnością Serbów podczas I wojny światowej. W kolejnej odniesiono się do funkcjonowania Królestwa Serbów, Chorwatów i Słoweńców, w którym Serbowie uzyskali znaczną przewagę polityczną nad innymi narodami południowosłowiańskimi. W trzeciej części przybliżono problematykę serbskiego autorytaryzmu w Królestwie Jugosławii, będącego jedną z przyczyn narastania konfliktu narodowościowego w państwie.

Outline of content: The article presents an outline of the Serbian political dominance in the federation of South Slavic peoples in the years 1918-1941. The first part recalls various aspects of Serbian activity during WWI. The next one refers to the political reality of the Kingdom of Serbs, Croats and Slovenes, where the Serbs have gained an important advantage over the other South Slavic peoples. The third part examines the phenomenon of Serbian authoritarianism in the Kingdom of Yugoslavia, one of the causes of the growing ethnic conflict in the country.

Słowa kluczowe: Jugosławia, Królestwo Serbów, Chorwatów i Słoweńców, Królestwo Jugosławii, Serbia, Serbowie

Keywords: Yugoslavia, Kingdom of Serbs, Croats and Slovenes, Kingdom of Yugoslavia, Serbia, Serbs

\section{Wprowadzenie}

Zasadniczym celem federacji narodów południowosłowiańskich, funkcjonującej w latach 1918-1941, było stworzenie państwa mogącego skuteczniej reprezentować interesy polityczne głównie Serbów i Chorwatów. Niewątpliwie przyczyną zjednoczenia Południowych Słowian był wielowiekowy reżim narzucony przez silniejszych sąsiadów. Ziemie zamieszkałe przez Chorwatów i Słoweńców były 
częścią Królestwa Węgierskiego, następnie Cesarstwa Austriackiego i Monarchii Austro-Węgierskiej. Natomiast Serbowie, Czarnogórcy przez kilka wieków zmagali się z Imperium Osmańskim. Setki lat panowania Węgrów, Austriaków czy Turków nie przekreśliły narodowowyzwoleńczych dążeń Słowian Południowych. Serbowie proklamowali Królestwo w 1882 r., natomiast Chorwaci i Słoweńcy na wyzwolenie swoich ziem musieli czekać aż do końca I wojny światowej. Należy odnotować, że idea jugoslawizmu swoje początki miała już w XIX wieku. Zarówno chorwaccy, jak i serbscy myśliciele głosili potrzebę powołania wspólnego bytu politycznego ${ }^{1}$. W tym miejscu warto wspomnieć o koncepcji Iliji Garašanina, którą przedstawił on jeszcze w 1844 r. w dokumencie zatytułowanym Načertanije. Serbski polityk wskazał na potrzebę zbudowania zjednoczonego państwa Słowian Południowych pod przywództwem Serbów² ${ }^{2}$ Jak się okazało idea Garašanina została częściowo wcielona w życie po I wojnie światowej ${ }^{3}$. Serbowie wraz z Chorwatami i Słoweńcami powołali Królestwo, które stało się filarem jugosłowiańskiej więzi w XX-leciu międzywojennym. Należy zaznaczyć, iż Serbowie, stanowiąc najliczniejszą grupę etniczną, zdominowali życie polityczne pierwszej Jugosławii. Serbska supremacja bezpośrednio przełożyła się na wrogość polityczną zwłaszcza ze strony Chorwatów, którzy domagali się federalizacji państwa. Tym samym umocnił się serbsko-chorwacki antagonizm, który jeszcze przed powołaniem wspólnego państwa dotyczył m.in.: wzajemnych roszczeń wobec terytorium Bośni i Hercegowiny czy też polityki chorwackiej Partii Prawa (Stranka prava) ${ }^{4}$. Niemożność wcielenia w życie postulatów zgłaszanych przez chorwackich polityków przełożyła się na permanentny konflikt wewnętrzny w jugosłowiańskim państwie. Ostatecznie pierwsza federacja narodów południowosłowiańskich uległa destrukcji ${ }^{5}$.

1 Na uwagę zasługuje działalność Josipa Juraja Strossmayera, chorwackiego polityka i duchownego. Był jednym z prekursorów idei jugoslawizmu i założycielem instytucji naukowej Jugosłowiańskiej (nie chorwackiej) Akademii Nauk i Sztuk Pięknych (Zagrzeb 1866 r.). J. K. Kox, The History of Serbia, Greenwood Press 2002, s. 68.

2 D. Stranjaković, Kako je postalo Garašaninovo „Načertanije”, Spomenik SKA, XCI, Beograd 1939, s. 76-102.

3 I. Garašanin uważał, że w południowosłowiańskiej federacji powinni znaleźć się również Bułgarzy. R. Ljušić, Ilija Grašanin on Serbia’s Statehood, „Balcanica” XXXIX (2008), Annual of the Institute for Balkan Studies, red. D. Bataković, Belgrade 2009, s. 160.

4 Partia Prawa powstała w 1861 r., przemianowana na Chorwacką Partię Prawa w 1919 r., rozwiązana w 1929 r., głosiła potrzebę powołania niepodległej Chorwacji, w sprawach południowosłowiańskich opowiadała się za zjednoczeniem wszystkich Słowian Południowych od Styrii po Macedonię w jednym narodowym państwie pod nazwą „Država Hrvatska”. W. Felczak, T. Wasilewski, Historia Jugosławii, Wrocław 1985, s. 351.

5 Autor, posługując się terminem pierwsza federacja narodów południowosłowiańskich (pierwsza Jugosławia), ma na myśli Królestwo SHS i Królestwo Jugosławii z lat 1918-1941; druga Jugosławia (Federacyjna Ludowa Republika Jugosławii, Socjalistyczna Federacyjna Republika Jugosławii) funkcjonowała w latach 1943 (1945)-1991; natomiast trzecia Jugosławia (Federalna Republika Jugosławii) w latach 1992-2003. Powyższą terminologię zastosował m.in. J. B. Allock (Explaining Yugoslavia, London 2000), J. Lampe (Yugoslavia as History: Twice there was a country, Cambridge University Press 
Celem artykułu jest określenie zasięgu oraz siły serbskiej hegemonii politycznej w Królestwie SHS i Królestwie Jugosławii oraz jej wpływu na sytuację wewnętrzną państwa. Natomiast nadrzędną tezą jest twierdzenie, że polityka serbskich decydentów miała bezpośrednie przełożenie na słabość jugosłowiańskiej federacji. Ponadto założeniem jest uznanie serbskiej dominacji politycznej za jedną z przyczyn narastania sporu narodowościowego (serbsko-chorwackiego) w XX-leciu międzywojennym.

\section{Serbowie podczas I wojny światowej (1914-1918)}

28 czerwca 1914 r. bośniacki Serb, Gavrilo Princip, zastrzelił w Sarajewie następcę tronu Austro-Węgier, arcyksięcia Franciszka Ferdynanda. To wydarzenie w znaczny sposób przyczyniło się do wybuchu I wojny światowej. Austriacy odpowiedzialnością za zabójstwo habsburskiego księcia obarczyli serbski rząd. Politycy Królestwa Serbii, $w$ tym premier N. Pašić, odrzucili oskarżenia ${ }^{6}$. Niestety wszelkie próby porozumienia okazały się nieskuteczne i dokładnie miesiąc po zamachu rząd AustroWęgier wypowiedział serbskiemu państwu wojnę. W tym kontekście ważna była grudniowa deklaracja serbskiej rady ministrów, w której określono cel wojny, jakim miało być „wyzwolenie i zjednoczenie wszystkich dotąd niewyzwolonych braci Serbów, Chorwatów i Słoweńców" ". Działania zbrojne jeszcze w 1914 r. przyniosły sukces doświadczonym w wojnach bałkańskich serbskim wojskom ${ }^{8}$. Kolejna ofensywa Państw Centralnych została przeprowadzona dopiero w październiku 1915 roku. Tym razem Austriacy wzmocnieni niemieckimi oddziałami szybko zdobyli Belgrad. Do walki z Serbami włączyły się również wojska bułgarskie, które skutecznie zamknęły drogę ewakuacyjną serbskim żołnierzom ${ }^{9}$. Beznadziejne położenie broniących się Serbów oraz groźba otoczenia przez nieprzyjaciół zmusiły serbskie dowództwo do wycofania wojsk przez trudno dostępne albańskie góry ku wybrzeżom Morza Adriatyckiego, a dalej na wyspę Korfu. Wraz z żołnierzami, Serbię opuszczali również intelektualiści, elita polityczna oraz ludność cywilna, a także król Piotr Karadjordjević. Na skutek zimowych warunków na wyspę Korfu

2000), D. Jović (Yugoslavia. A State that Withered Away, Purdue University Press 2009), L. Podhorodecki (Jugosławia. Dzieje narodów, państw i rozpad federacji, Warszawa 2000).

6 Należy zaznaczyć, iż austro-węgierscy militaryści jeszcze przed zamachem sarajewskim ujawniali zamiar zaatakowania Serbii, wojny „prewencyjnej” żądał m.in. austro-węgierski szef sztabu Conrad von Hotzendorf. H. Batowski, Rozpad Austro-Wegier 1914-1918 (Sprawy narodowościowe i działania dyplomatyczne), Kraków 1982, s. 101.

7 W. Felczak, T. Wasilewski, op. cit., s. 419; I. Banac, The National Question in Yugoslavia: Origins, History, Politics, Cornell University Press 1984, s. 116; M. Đorđević, Z. Gudac, Savremena politika istorija Srbije, Crne Gore i SR Jugoslavije, Beograd 1995, s. 23.

8 V. Drapac, Constructing Yugoslavia. A transnational history, Basingstoke 2010, s. 71.

9 W 1915 r. Bułgaria wraz z Niemcami, Austro-Węgrami i Turcją utworzyła tzw. Czwórprzymierze, sojusz militarny skierowany przeciw państwom Ententy. Bułgarzy w zamian za pomoc w walkach z Serbami mieli otrzymać serbską część Macedonii. Zob. T. Szymczak, Jugosławia - państwo federacyjne, Łódź 1982, s. 24. 
z grupy ok. 420 tys. dotarło zaledwie 150 tys. uchodźców ${ }^{10}$. Serbowie natychmiast zreorganizowali armię, która już we wrześniu 1916 r. walczyła wraz z innymi wojskami państw Ententy na froncie salonickim. Niestety, zarówno wrześniowa ofensywa, jak i późniejsze próby przełamania frontu okazały się bezskuteczne i aż do października 1918 r. sytuacja nie uległa zmianie ${ }^{11}$.

Znacznie korzystniej od spraw militarnych zarysowywała się kwestia kształtowania się reprezentacji politycznej Serbów i innych Słowian na uchodźstwie. Na Korfu swoje prace kontynuował serbski rząd pod przywództwem Nikoli Pašicia. Ponadto już od 1915 r. funkcjonował w Londynie tzw. Komitet Jugosłowiański, powołany przez zwolenników idei utworzenia wspólnego państwa Południowych Słowian ${ }^{12}$. Należy zaznaczyć, iż serbska rada ministrów zdominowana przez przedstawicieli Partii Radykalnej aż do połowy 1917 r. stała na stanowisku ponownego odbudowania serbskiej państwowości. Dopiero tzw. deklaracja majowa z 1917 r. wpłynęła na zmianę tych oczekiwań. W powyższym dokumencie jugosłowiańscy posłowie do austriackiej Rady Państwa wyrazili myśl zjednoczenia Słoweńców, Serbów i Chorwatów w jednym państwie pod dynastią habsburską ${ }^{13}$. Rząd serbski na te poczynania odpowiedział uchwaleniem w lipcu 1917 r. tzw. deklaracji z Korfu ${ }^{14}$. W ten sposób Serbowie po raz pierwszy w oficjalnym dokumencie poparli ideę zjednoczenia wszystkich Jugosłowian w jednym Królestwie ${ }^{15}$. Również Komitet Jugosłowiański zadeklarował swój wkład w dalsze prace nad powołaniem nowego państwa.

\section{Serbska hegemonia w Królestwie Serbów, Chorwatów i Słoweńców (1918-1929)}

Wyzwolenie Bałkanów nastąpiło dopiero jesienią 1918 roku. Dwumiesięczna ofensywa połączonych sił państw Ententy, w których filar stanowiły serbskie dywizje, oswobodziła ziemie dawnego Królestwa Serbii. Belgrad ponownie wrócił pod serbski zarząd 1 listopada 1918 roku $^{16}$. Niestety, podczas I wojny światowej Serbowie ponieśli potężne straty ludnościowe. Według oficjalnych obliczeń jej łączne ubytki

10 W. Felczak, T. Wasilewski, op. cit., s. 422.

11 М. Бјелајац, Дипломатија и војска. Србија и Југославија 1901-1999, Београд 2010, s. 71-80.

12 Zarówno serbscy, jak i chorwaccy politycy uważali, iż powołanie po wojnie wspólnego państwa - Jugosławii - będzie najlepszą barierą przed włoskim i niemieckim ekspansjonizmem. D. Djokic, Nikola Pašić and Ante Trumbić. The Kingdom of Serbs, Croats and Slovenes, London 2010, s. 46.

13 Deklaracija Jugoslovenskoga kluba, Beč, 30 maja 1917, [w:] F. Šišić, Dokumenti o postanku Kraljevine Srba, Hrvata i Slovenaca 1914-1919, Zagreb 1920, s. 94; W. Felczak, T. Wasilewski, op. cit., s. 426.

14 Pełny tekst deklaracji z Korfu (7 lipca 1917 r.): Yugoslavia through documents: from its creation to its dissolution, red. S. Trifunovska, Amsterdam 1994, s. 141-142; Krfska Deklaracija od 20. (7.) jula 1917, [w:] F. Šišić, op. cit., s. 96-99.

15 L. Benson, Jugosławia. Historia w zarysie, Kraków 2011, s. 32; M. Pułaski, Z dziejów genezy Europy Wersalskiej. Współpraca Słowian zachodnich i południowych w ostatnim etapie I wojny światowej, Warszawa 1974, s. 30.

16 F. Slipičevič, Istorija naroda Socijalističke Federativne Republike Jugoslavije. Novi Vijek, Sarajevo 1964, s. 260. 
oszacowano na około 1250 tys., co stanowiło 28\% przedwojennego stanu ludności ${ }^{17}$. Tymczasem jeszcze w październiku rozpadło się Cesarstwo Austro-Węgier, stwarzając odpowiednie warunki dla ukonstytuowania jugosłowiańskiego państwa ${ }^{18}$. Na przełomie 8 i 9 listopada Nikola Pašić, reprezentujący serbski rząd, Anton Korošec z zagrzebskiej Rady Narodowej oraz Ante Trumbić z Komitetu Jugosłowiańskiego, podpisali deklarację genewską, w świetle której miano powołać jugosłowiańską radę ministrów ${ }^{19}$. Pod koniec listopada Czarnogórcy oraz Serbowie z Wojwodiny zatwierdzając inkorporację swoich terytoriów do serbskiej państwowości, przyczynili się do wzmocnienia politycznej pozycji Serbów ${ }^{20}$. Ostatecznie 1 grudnia 1918 r. następca Króla Serbii, Piotra Karadjordjevicia, książę Aleksander, proklamował Królestwo Serbów, Chorwatów i Słoweńców (Kraljevina Srba, Hrvata i Slovenaca) ${ }^{21}$. Na czele jugosłowiańskiego rządu stanął Serb, wywodzący się z Narodowej Partii Radykalnej, Stojan Protić ${ }^{22}$. Kluczowe funkcje w utworzonej radzie ministrów pełnili również Serbowie $^{23}$. Należy zaznaczyć, że akt zjednoczeniowy był krytykowany przez opozycyjne ośrodki w Zagrzebiu, Lublanie i Sarajewie za usankcjonowanie dominacji serbskiej w wielonarodowym państwie ${ }^{24}$.

W tym też okresie jednym z ważniejszych problemów nowo powstałego państwa była kwestia granic. Serbowie, walczący podczas I wojny światowej po stronie Ententy, wykorzystali swoją uprzywilejowaną pozycję i poszerzyli obszar dawnego Królestwa Serbii. Przyłączono nie tylko Wojwodinę, będącą przed wojną w granicach Austro-Węgier, ale również nadgraniczny pas ziem bułgarskich, ciągnący się od Dunaju aż po granicę z Grecją ${ }^{25}$. Jednocześnie serbscy żołnierze przejęli kontrolę na terenach zamieszkiwanych przez inne słowiańskie nacje (głównie w chorwackiej

17 W. Szulc, Przemiany gospodarcze i społeczne w Jugosławii w okresie międzywojennym 1918-1941, Poznań 1980, s. 38.

1829 października 1918 r. Rada Narodowa Słoweńców, Chorwatów i Serbów ogłosiła się jedynym politycznym organem na ziemiach jugosłowiańskich w Austro-Węgrzech i proklamowała utworzenie niepodległego i demokratycznego Państwa Słoweńców, Chorwatów i Serbów. M. Tanty, Bałkany w XX wieku. Dzieje polityczne, Warszawa 2003, s. 148.

19 Ponadto w deklaracji genewskiej znalazła się wzmianka o potrzebie uchwalenia konstytucji, wspólnej dla Serbów, Chorwatów i Słoweńców oraz ustanowienia granic państwa w zgodzie z prawami obywatelskimi i prawem do samostanowienia każdego narodu. Zob. Ženevska deklaracija od 9. nov. 1918, [w:] F. Šišić, op. cit., s. 236-237.

20 W. Balcerak, Powstanie państw narodowych $w$ Europie Srodkowo-Wschodniej, Warszawa 1974, s. 366 i 376.

21 Królestwo Serbów, Chorwatów i Słoweńców powstało w wyniku zjednoczenia Królestwa Serbii z ziemiami niepodległego Państwa Słoweńców, Chorwatów i Serbów w oparciu o uchwałę Rady Narodowej SHS z 24 listopada 1918 r., Ibidem, s. 378.

22 L. Podhorodecki, op. cit., s. 149.

23 J. Skowronek, M. Tanty, T. Wasilewski, Historia Słowian Południowych i Zachodnich, Warszawa 1988, s. 625.

24 D. Skulic, The creation and dissolution of the multinational state: the case of Yugoslavia, „Nations and Nationalism" 1997, nr 3 (2), s. 171.

25 W. Balcerak, op. cit., s. 395-396. 
Slawonii i Dalmacji) ${ }^{26}$. Bez wątpienia w Królestwie SHS terytorialnie i ludnościowo dominowali Serbowie, co też miało niebagatelne przełożenie na politykę państwa ${ }^{27}$. Serbscy politycy zjednoczeni głównie w Narodowej Partii Radykalnej kontrolowali życie polityczne jugosłowiańskiego państwa. Pomimo iż nie uzyskali większości w Zgromadzeniu Ustawodawczym, to oni dyktowali warunki innym partiom politycznym ${ }^{28}$. Wyznaczali nie tylko kierunki polityki zagranicznej, ale też mieli duży wpływ na politykę wewnętrzną i kształt pierwszej jugosłowiańskiej konstytucji ${ }^{29}$.

Ustawa Zasadnicza została uchwalona 28 czerwca 1921 r., w dniu św. Wida i 532 rocznicę bitwy na Kosowym Polu (stąd nazwa Konstytucja widowdańska - Vidovdanski $\left.U s t a v^{30}\right)$. Konstytucja ustanowiła m.in. monarchię dziedziczną oraz wprowadziła pojęcie narodowości jugosłowiańskiej, wspólnej dla wszystkich obywateli. Poza tym w znacznym zakresie ograniczyła kompetencje rządu oraz parlamentu na rzecz poszerzonych uprawnień monarchy ${ }^{31}$. Jednakże najbardziej konfliktogenny był zapis o nowym podziale administracyjnym państwa. Zamiast podziału na historycznie ukształtowane kraje miał nastąpić podział na obwody, okręgi, powiaty i gminy (ograniczający prawa organów samorządowych) ${ }^{32}$. Bez wątpienia celem ośrodka decyzyjnego było zawężenie możliwości rozwoju ruchów narodowowyzwoleńczych, zwłaszcza w Chorwacji i w Słowenii. Tym samym nastąpiła natychmiastowa radykalizacja postaw przede wszystkim wśród Chorwatów. Zabójstwo ministra spraw wewnętrznych, Milorada Draškovicia, i nieudany zamach na monarchę nie wpłynęły na zmianę centralistycznej polityki. Król Aleksander jeszcze w kwietniu 1922 r. wystosował dekret sankcjonujący kontrowersyjny podział administracyjny Królestwa SHS.

Wkrótce serbscy politycy umocnili swoją przewagę polityczną w państwie, odsuwając od najważniejszych stanowisk przedstawicieli innych nacji. Najbardziej zaciekły antagonizm narodowy rozgorzał między Serbami a Chorwatami ${ }^{33}$. Chorwaci nadal

26 Serbska armia (na chorwackich ziemiach) już w 1919 r. była postrzegana przez Chorwatów jako siły okupacyjne. Zob. J. P. Newman, Post-imperial and Post-war Violence in the South Slav Lands, 1917-1923, „Contemporary European History” 2010, nr 19 (3), s. 257.

27 Królestwo SHS rozciągało się na ok. 249 tys. $\mathrm{km}^{2}$ i liczyło niecałe $12 \mathrm{mln}$ ludzi. Terytorium Serbii (w granicach Królestwa SHS) wynosiło ponad 95 tys. km² , natomiast populacja ok. 4 mln. Zob. W. Szulc, op. cit., s. 39; P. Eberhardt, Przemiany demograficzno-etniczne na obszarze Jugostawii w XX wieku, Lublin 2005, s. 103-105.

28 Wyniki wyborów do Zgromadzenia Ustawodawczego z XI 1920 r.: Serbska Partia Demokratyczna - 92 mandaty, Narodowa Partia Radykalna - 91 mandatów, Komunistyczna Partia Jugosławii - 58 mandatów, Chorwacka Republikańska Partia Chłopska - 50 mandatów, Związek Rolników Serbskich - 39 mandatów, Słoweńska Partia Ludowa - 27 mandatów, Organizacja Muzułmanów Jugosłowiańskich - 24 mandaty. Dane za: W. Walkiewicz, Jugosławia. Państwa sukcesyjne, Warszawa 2009, s. 60.

29 Jak wskazuje V. Drapac, zatwierdzenie kontrowersyjnej i centralistycznej konstytucji skutecznie zapewniło dominację Serbom i serbskim instytucjom w nowym państwie. V. Drapac, op. cit., s. 97.

30 Ustav Kraljevine Srba, Hrvata i Slovenaca, Službene novine Kraljevine SHS, od 28. juna 1921. godine.

31 Na temat Konstytucji Królestwa Serbów, Chorwatów i Słoweńców z 1921 r. czyt. więcej: T. Szymczak, op. cit., s. 46-52; M. Đorđević, Z. Gudac, op. cit., s. 26.

32 W. Balcerak, op. cit., s. 411.

33 B. Jelavich, Historia Bałkanów. Wiek XX, Kraków 2005, s. 167. 
dążyli do szerokiej autonomii i nie akceptowali centralistycznych działań Serbów. Najsilniejsze chorwackie ugrupowanie polityczne - Partia Chłopska ze Stjepanem Radiciem na czele - właściwie od ukonstytuowania Królestwa SHS rywalizowała z serbskimi radykałami o kształt ustrojowy państwa. Zarówno S. Radić, jak i inni nie-serbscy politycy nie mieli możliwości zrealizowania federalistycznych planów. Serbscy radykałowie skutecznie zwalczali politycznych oponentów bądź też ograniczali ich aktywność. W 1921 r. zdelegalizowano Komunistyczną Partię Jugosławii, natomiast poczynania chorwackich agrarystów były stale nadzorowane. Ostatecznie w styczniu 1925 r., na miesiąc przed wyborami parlamentarnymi S. Radić wraz z najbliższymi współpracownikami trafili do aresztu ${ }^{34}$. Pomimo absencji liderów chorwackiej Partii Chłopskiej, wybory do Skupštiny nie zmieniły jej partyjnego oblicza. Zgromadzeni w tzw. Bloku Narodowym, serbscy radykałowie nadal dominowali, jednakże ich przewaga była symboliczna ${ }^{35}$. Natychmiast po wyborach uwolniono chorwackich dysydentów, co więcej, przyznano im teki ministerialne ${ }^{36}$. Jednakże współpraca serbskich radykałów z chorwackimi agrarystami była krótkotrwała i nie zaowocowała stabilizacją państwa.

Koniec 1926 r. zwiastował zmianę oblicza jugosłowiańskiej polityki, na którą wpłynęła śmierć wieloletniego premiera, charyzmatycznego serbskiego polityka Nikoli Pašicia ${ }^{37}$. Należy zaznaczyć, iż N. Pašić integrował wokół swojej osoby nie tylko serbskich radykałów, ale też polityków z innych ugrupowań. W ten sposób zjednoczona polityczna reprezentacja Serbów mogła skutecznie utrzymywać władzę w multietnicznym państwie. Już w 1927 r. doszło do rozłamu, Partia Demokratyczna kierowana przez chorwackiego Serba, Svetozara Pribićevicia przeszła na stronę opozycji. Demokraci wzmocnili blok federalistyczny, przez co mógł on skuteczniej powstrzymywać politykę strony rządzącej ${ }^{38}$. Przez kolejne miesiące w Królestwie SHS trwał permanentny kryzys polityczny ${ }^{39}$. Kulminacją narastających sporów były wydarzenia z 20 czerwca 1928 roku. Podczas parlamentarnych obrad członek Partii Radykalnej, Serb z Czarnogóry, Puniša Račić, zastrzelił dwóch chorwackich posłów i ranił trzech innych, w tym S. Radicia (jak się okazało śmiertelnie) ${ }^{40}$.

34 W. Walkiewicz, op. cit., s. 75.

35 Wyniki wyborów parlamentarnych z lutego 1925 r.: Blok Narodowy (Narodowa Partia Radykalna) - 164 mandaty, zjednoczona centrolewica (Serbska Partia Demokratyczna, Słoweńska Partia Ludowa, Organizacja Muzułmanów Jugosłowiańskich) wspierana przez zdelegalizowane: Komunistyczną Partię Jugosławii oraz Chorwacką Republikańską Partię Chłopska - 151 mandatów. Dane za: Ibidem, s. 75.

36 S. Radić otrzymał stanowisko Ministra Edukacji. T. Judah, The Serbs. History, Myth and the Destruction of Yugoslavia, London 1997, s. 109.

37 D. Djokic, op. cit., s. 158.

38 Partia Demokratyczna wraz z Chorwacką Partią Chłopską utworzyła Koalicję Chłopsko-Demokratyczną, której przewodzili S. Radić i S. Pribićević.

39 W okresie 10 lat istnienia Królestwa SHS (1918-1928) wystąpiły aż 24 kryzysy rządowe. W. Szulc, op. cit., s. 34 .

40 M. Glenny, The Balkans. Nationalism, War and the Great Powers 1804-1999, New York 2000, s. $408-412$. 
Groźba rewolucji w Chorwacji zmusiła króla Aleksandra do zerwania z przyjętym zwyczajem mianowania serbskiego polityka na stanowisko premiera. Jeszcze w lipcu powołano na prezesa rady ministrów Słoweńca, Antona Korošeca ${ }^{41}$. Reorganizacja rządu nie zahamowała rosnącego napięcia. W tak zakreślonych realiach politycznych jugosłowiański monarcha nie ugiął się pod presją opozycji. Absolutnie odrzucił ideę przekształcenia Królestwa SHS w federację państw słowiańskich. Tym samym grudniowe obchody 10-lecia istnienia państwa zbiegły się z zamieszkami i demonstracjami przede wszystkim w chorwackich miastach. Na początku stycznia 1929 r. król zawiesił konstytucję, rozwiązał Skupštinę i wszystkie partie polityczne ${ }^{42}$. Niewątpliwie Aleksander dopuścił się zamachu na konstytucyjne organy państwa i zapoczątkował okres kilkuletniej dyktatury (tzw. Šestojanuarska diktatura). Na fotel premiera został powołany serbski generał Petar Živković. Nastąpiły liczne aresztowania oponentów politycznych, głównie polityków identyfikujących się z lewicowymi poglądami ${ }^{43}$. Monarcha nie tylko nie dopuścił do życia publicznego partii politycznych, ale też skutecznie ograniczył działalność ich liderów (m.in. przywódca Partii Demokratycznej - S. Pribićević został internowany, natomiast nowy lider Chorwackiej Partii Chłopskiej - V. Maček - został aresztowany).

Tabela 1. Premierzy Królestwa SHS (XII 1918-XI 1929)

\begin{tabular}{|l|l|l|l|}
\hline Premier & Narodowość & Partia polityczna & Okres urzędowania \\
\hline 1. Stojan Protić & Serb & Narodowa Partia Radykalna & 22 XII 1918-16 VIII 1919 \\
\hline 2. Ljubomir Davidović & Serb & Partia Demokratyczna & 16 VIII 1919-19 II 1920 \\
\hline 3. Stojan Protić & Serb & Narodowa Partia Radykalna & 19 II 1920-16 V 1920 \\
\hline 4. Milenko Vesnić & Serb & Narodowa Partia Radykalna & 16 V 1920-1 I 1921 \\
\hline 5. Nikola Pašić & Serb & Narodowa Partia Radykalna & 1 I 1921-28 VII 1924 \\
\hline 6. Ljubomir Davidović & Serb & Partia Demokratyczna & 28 VII 1924-6 XI 1924 \\
\hline 7. Nikola Pašić & Serb & Narodowa Partia Radykalna & 6 XI 1924-8 IV 1926 \\
\hline 8. Nikola Uzunović & Serb & Narodowa Partia Radykalna & 8 IV 1926-17 IV 1927 \\
\hline 9. Velimir Vukićević & Serb & Narodowa Partia Radykalna & 17 IV 1927-28 VII 1928 \\
\hline 10. Anton Korošec & Słoweniec & Słoweńska Partia Ludowa & 28 VII 1928-7 I 1929 \\
\hline 11. Petar Živković & Serb & bezpartyjny (dyktatura) & 7 I 1929-3 XI 1929 \\
\hline
\end{tabular}

Źródło: opracowanie własne

\section{Serbski autorytaryzm w Królestwie Jugosławii (1929-1941)}

W październiku 1929 r. na mocy królewskiego dekretu Królestwo Serbów, Chorwatów i Słoweńców zostało przemianowane na Królestwo Jugosławii (Kraljevina

41 T. Szymczak, op. cit., s. 64.

42 W. Walkiewicz, op. cit., s. 83; pełny tekst królewskiego ukazu uchylającego konstytucję i rozwiązującego parlament Królestwa SHS z 6 stycznia 1929 r.: Yugoslavia through ..., s. 190-191; F. Čulinovič, Dokumenti o Jugoslaviji, Historijat od osnutka zajedničke države do danas, Zagreb 1968, s. 294.

43 J. Skowronek, M. Tanty, T. Wasilewski, op. cit., s. 644-645. 
Jugoslavija $)^{44}$. Ponadto zreformowano dotychczasowy podział administracyjny. Przekształcono obwody w dziewięć prowincji, tzw. banoviny, ściśle podporządkowane władzy centralnej ${ }^{45}$. Terytoria banovin zostały wyznaczone w sposób faworyzujący Serbów (aż w sześciu prowincjach Serbowie stanowili większość) ${ }^{46}$. Głównym celem króla Aleksandra była neutralizacja sporów narodowych, jednak nie na drodze negocjacji i partnerstwa lecz poprzez narzucony reżim. W kreowanej przez siebie strategii wyraźnie kierował się zasadą skupienia władzy państwowej w swoich rękach ${ }^{47}$. Również nie bez znaczenia był fakt, iż większość stanowisk państwowych, jak i samorządowych piastowali Serbowie. Pozostałe nacje, w tym głównie Chorwaci, nie miały wpływu na życie polityczne w Królestwie Jugosławii.

Stwarzająca pozory demokracji dyktatura Aleksandra uzyskała umocowanie prawne. Od 3 września 1931 r. zaczęła obowiązywać nowa konstytucja jugosłowiańskiego państwa ${ }^{48}$. Ustawa zasadnicza utworzyła dwuizbowy parlament, ograniczony władzą monarchy, niemogący samodzielnie stanowić prawa. Przywrócono zdelegalizowane partie polityczne, z tym że ich działalność nie mogła odbiegać od linii politycznej monarchy (partie narodowe czy też regionalne były nadal nielegalne ${ }^{49}$. Bezsprzecznie konstytucja Królestwa Jugosławii z 1931 r. przekazywała monarsze szerokie uprawnienia i stworzyła prawne podstawy dla państwa o autorytarnym ustroju $^{50}$. Listopadowe wybory parlamentarne potwierdziły dominującą pozycję serbskich polityków. Wszystkie mandaty poselskie uzyskała nowo powstała koalicja Jugosłowiańska Radykalna Chłopska Demokracja (przemianowana w 1934 r. na Jugosłowiańską Partię Narodową). Pozostałe ugrupowania polityczne zbojkotowały wybory lub też nie zostały do nich dopuszczone. Na czele rządu ponownie stanął Petar Živković.

Przez kolejnych kilka lat oblicze polityczne Jugosławii nie uległo zmianie. Państwem despotycznie zarządzał król Aleksander wspierany przez serbskich stronników. Politycy będący w opozycji bądź też innej narodowości byli często więzieni lub zmuszani do emigracji ${ }^{51}$. Wydalony z kraju lider zdelegalizowanej Partii Demokratycznej, S. Pribićević, skonstruował blok opozycyjny, ale jego działania, jak i innych antycentralistycznych polityków były bezskuteczne. Trudne położenie oponentów

44 Art. 1, Law altering the appellation and administrative divisions of the Kingdom of the Serbs, Croats and Slovenes, Belgrade, 3 October 1929, [w:] Yugoslavia through..., s. 195.

45 Art. 2, Ibidem, s. 195.

46 B. Jelavich, op. cit., s. 216.

47 L. Benson, op. cit., s. 73.

48 M. Tanty, op. cit., s. 181; L. Krkljuš, S. Šarkić, Odabrani izvori iz državnopravne istorije Jugoslavije, Beograd 1998, s. 305-313.

49 B. Jelavich, op. cit., s. 216.

50 Monarcha stanowił władzę wykonawczą oraz ustawodawczą (dzieloną z parlamentem). Miał prawo zawieszenia konstytucji, zwoływania i odwoływania zgromadzenia narodowego. Ponadto nominował połowę składu senatu. Art. 29-35, 50, 66, 77-78, Ustav Kraljevine Jugoslavije (Oktroisani ustav), Službene novine Kraljevine Jugoslavije, od 3. septembra 1931. godine.

51 W 1933 r. V. Maček został skazany na 3 lata więzienia, natomiast A. Korošeca internowano na wyspie Hvar. 
monarchii wymusiło na nich przejście do walki podziemnej i organizowanie akcji terrorystycznych ${ }^{52}$. Najważniejszym celem spiskowców było usunięcie jugosłowiańskiego króla. Założenie zostało zrealizowane 9 października 1934 roku. Podczas dyplomatycznej wizyty w Marsylii, król Aleksander został zastrzelony (wraz z nim zginął towarzyszący mu francuski minister spraw zagranicznych, Louis Barthou). Zabójcą okazał się instruowany przez Ustaszy macedoński rewolucjonista Veliko Georgiev Kerin (znany również jako Vlada Georgiev Chernozemski) ${ }^{53}$.

Tron Królestwa Jugosławii przypadł nieletniemu synowi Aleksandra, Piotrowi II, jednakże faktyczną władzę sprawował krewny zamordowanego monarchy, książę Paweł Karadjordjević ${ }^{54}$. Regent, choć nie wykazywał się dyktatorskim charakterem, dążył do utrzymania scalonej Jugosławii. Przejawem dobrych zamiarów księcia było odstąpienie od prześladowań opozycyjnych polityków. Niestety, relacje między narodami jugosłowiańskiego państwa nadal były napięte. Serbscy decydenci różnych szczebli administracji publicznej nie dopuszczali do swoich stanowisk przedstawicieli innych narodowości. Na początku 1935 r. rozwiązano parlament i zarządzono nowe wybory, które miały odbyć się według ordynacji wyborczej z 1931 roku. Unormowania te wyraźne faworyzowały najsilniejsze ugrupowanie, jakim bez wątpienia była Jugosłowiańska Partia Narodowa, de facto reprezentująca tylko serbskie interesy. Zgodnie z oczekiwaniami 5 maja 1935 r. niezaprzeczalne zwycięstwo w wyborach parlamentarnych odnieśli Serbowie. Przedstawiciele Jugosłowiańskiej Partii Narodowej uzyskali 303 mandaty poselskie. Pozostałe 67 przypadło zjednoczonej opozycji, do której przyłączyła się m.in. Chorwacka Partia Chłopska oraz Partia Demokratyczna ${ }^{55}$. Opozycyjni posłowie ponownie zbojkotowali Skupštinę i nie przyjęli mandatów poselskich. Swoją postawę tłumaczyli niesprawiedliwym podziałem mandatów ${ }^{56}$.

Powstały w czerwcu 1935 r. kolejny „serbski” rząd z Milanem Stojadinoviciem na czele wyznaczył sobie za priorytetowy cel liberalizację polityki wewnętrznej państwa. Pomimo iż premier zaprosił do współpracy słoweńskich i muzułmańskich polityków, spór z Chorwatami nadal wpływał destrukcyjnie na stabilność jugosłowiańskiego państwa. Ponadto zarysował się problem związany z Kosowem. Tam-

52 Na początku lat 30. XX w. największą aktywnością podziemną wykazali się członkowie Komunistycznej Partii Jugosławii, Wewnętrznej Macedońskiej Organizacji Rewolucyjnej oraz Ustasze. J. Lampe, op. cit., s. 173-176.

53 J. Tomašević, War and Revolution in Yugoslavia, 1941-1945: Occupation and Collaboration, Stanford University Press 2001, s. 33; T. Judah, op. cit., s. 111.

54 Książę Paweł Karadjordjević (1893-1976) był synem księcia Arsena Karadjordjevicia - brata króla Piotra I, nie miał doświadczenia wojskowego i politycznego, interesował się głównie podróżami. Wykształcenie zdobył na Oksfordzie, gdzie zawiązał ścisłe relacje z Anglikami (w tym z członkami parlamentu). Zob. V. Drapac, op. cit., s. 146-147.

55 A. N. Draganich, The First Yugoslavia: Search for a Viable Political System, Hoover Institution Press 1983, s. 102; W. Felczak, T. Wasilewski, op. cit., s. 460.

56 Jugosłowiańska Partia Narodowa gromadząc ok. 60\% głosów wyborczych (ok. 1,7 mln) uzyskała ok. 82\% mandatów (303). Natomiast Koalicja Chłopsko-Demokratyczna, mając ok. 40\% poparcie (ok. 1,1 mln), zdobyła zaledwie 18\% mandatów (67). A. N. Draganich, op. cit., s. 102. 
tejsza społeczność, używająca języka albańskiego, nie stawiała sobie jeszcze celów, które powodowałyby konflikt z patriotami serbskimi ${ }^{57}$. Jednakże populacja Serbów w stosunku do populacji Albańczyków przedstawiała się nader niekorzystnie. Z tego względu rozważano idee dealbanizacji południowych rubieży państwa lub też zasiedlenia ich serbskimi osadnikami ${ }^{58}$. Polityczno-społeczne problemy Królestwa Jugosławii oraz napięta sytuacja międzynarodowa zmusiły obóz rządzący do odłożenia wszelkich planów związanych z Kosowem.

Jugosłowiański układ partyjny uległ nieznacznym przekształceniom. Premier M. Stojadinović jeszcze w 1935 r. powołał nowe ugrupowanie - Jugosłowiańską Wspólnotę Radykalną (Jugosłowiańską Unię Radykalną). W szeregach powołanej partii, oprócz serbskich radykałów, znaleźli się również muzułmanie oraz Słoweńcy ${ }^{59}$. Pomimo multietnicznego charakteru nowo powstałego stronnictwa politycznego reprezentowało ono wyłącznie serbskie interesy. Warto również wspomnieć, iż w tym czasie wykształciła się też serbska grupa o nazwie Jugosłowiański Ruch Narodowy, znana jako Zbor (zrzeszenie), której ideologia skupiała się wokół centralizmu i nacjonalizmu serbskiego ${ }^{60}$. Natomiast trzon opozycji nie uległ zmianie i nadal stanowiły go partie bojkotujące jugosłowiański parlament. Należy zaznaczyć, iż w okresie umacniania się faszyzmu w Europie coraz większą popularność zdobywała wśród Chorwatów organizacja nacjonalistyczna - Ustaša (Ustasze).

Pod koniec lat 30. XX w. obóz rządzący (również opozycyjny), dążąc do wzmocnienia swojej pozycji politycznej, zawiązał sojusze z przedstawicielami innych państw lub ponadnarodowymi organizacjami. Naturalnymi sojusznikami Serbów pozostali Francuzi, Rumuni oraz Grecy (kontakty z komunistyczną Rosją zostały zerwane jeszcze w latach 20.). Największego zagrożenia upatrywano w Węgrach (mogących domagać się zwrotu Wojwodiny), Bułgarach (chcących pozyskać Macedonię) oraz Włochach (budujących swoje wpływy w Albanii). Członkowie rządu M. Stojadinovicia szukali wsparcia nie tylko w Paryżu i w Londynie, ale również w Berlinie. W następstwie dyplomatycznych rozmów podpisano mało znaczące deklaracje przyjaźni czy też nieagresji ${ }^{61}$. Tymczasem postępujący europejski kryzys oraz problemy wewnętrzne państwa zmusiły jugosłowiańskiego premiera do rozpisania w grudniu 1938 r. przyspieszonych wyborów parlamentarnych. Zgodnie z oczekiwaniami zwyciężył dotychczasowy obóz rządzący - Jugosłowiańska Wspólnota Radykalna. Opozycja, której przewodził V. Maček, pomimo blisko 45\% poparcia, uzyskała

57 W. Walkiewicz, op. cit., s. 98.

58 Na jednym ze spotkań Serbskiego Klubu Kulturalnego w Belgradzie (jakie miały miejsce w latach 1937-1939), V. Čubrilović, były członek „Młodej Bośni”, ówczesny wykładowca historii na Uniwersytecie Belgradzkim, zaproponował usunięcie Albańczyków z Kosowa, stosując szeroki wachlarz represji (na wzór „wysiedleń” Żydów w III Rzeszy). N. Malcolm, Kosovo. A short history, London 1998, s. 284.

59 J. Skowronek, M. Tanty, T. Wasilewski, op. cit., s. 650.

60 B. Jelavich, op. cit., s. 218.

61 M.in. z Bułgarią i Włochami: Ugovor o vecnom prijateljstvu s Bugarskom, 24. januara 1937: Politički sporazum izmedu Italije i Jugoslavije, 24. marta 1937, zob. B. Petranović, M. Zečević, Jugosla vija 1918-1988: tematska zbirka dokumenata, Beograd 1988, s. 369-371. 
zaledwie 67 mandatów. Pozostałych 306 miejsc poselskich w Skupštinie otrzymali politycy ugrupowania kierowanego przez M. Stojadinovicia ${ }^{62}$.

Ostatni rząd Królestwa Jugosławii skonstruował Serb Dragiša Cvetković. Decyzja regenta Pawła Karadjordjevicia o zmianie osoby na stanowisku premiera państwa wynikła z nieskutecznej polityki M. Stojadinovicia ${ }^{63}$. Największym sukcesem D. Cvetkovicia było osiągnięcie serbsko-chorwackiego porozumienia (sporazum ${ }^{64}$ ), na mocy którego powołano Banowinę Chorwacką - autonomię w granicach monarchii ${ }^{65}$. Niestety, rozwiązanie najtrudniejszego problemu wewnętrznego, z jakim przeszło dwie dekady borykali się jugosłowiańscy decydenci, zbiegło się z wybuchem II wojny światowej. W początkowej fazie konfliktu rząd Królestwa Jugosławii ogłosił neutralność. Pomimo wsparcia dyplomatycznego ze strony angielskiego oraz francuskiego rządu, naciski ze strony niemieckich i włoskich nazistów ostatecznie zmusiły jugosłowiańskie władze do działań wojennych. Ostatecznie Królestwo Jugosławii upadło, a poszczególne narody, które od 1918 r. współtworzyły państwo, znalazły się we wrogich sojuszach.

Tabela 2. Premierzy Królestwa Jugosławii (XI 1929-III 1941)

\begin{tabular}{|l|l|l|l|}
\hline Premier & Narodowość & Partia polityczna & Okres urzędowania \\
\hline 1. Petar Živković & Serb & $\begin{array}{l}\text { Jugosłowiańska Radykalna Chłopska } \\
\text { Demokracja }\end{array}$ & 3 XI 1929-4 VI 1932 \\
\hline 2. Vojislav Marinković & Serb & $\begin{array}{l}\text { Jugosłowiańska Radykalna Chłopska } \\
\text { Demokracja }\end{array}$ & 4 VI 1932-3 VII 1932 \\
\hline 3. Milan Srškić & Serb & $\begin{array}{l}\text { Jugosłowiańska Radykalna Chłopska } \\
\text { Demokracja }\end{array}$ & 3 VII 1932-27 I 1934 \\
\hline 4. Nikola Uzunović & Serb & $\begin{array}{l}\text { Jugosłowiańska Radykalna Chłopska } \\
\text { Demokracja (po przemianowaniu } \\
\text { w 1934 r., Jugosłowiańska Partia } \\
\text { Narodowa) }\end{array}$ & 27 I 1934-22 XII 1934 \\
\hline 5. Bogoljub Jevtić & Serb & $\begin{array}{l}\text { Jugosłowiańska Partia Narodowa; } \\
\text { Jugosłowiańska Wspólnota Radykalna od } \\
\text { 1935 r. }\end{array}$ & 22 XII 1934-24 VI 1935 \\
\hline 6. Milan Stojadinović & Serb & Jugosłowiańska Wspólnota Radykalna & 24 VI 1935-3 II 1939 \\
\hline 7. Dragiša Cvetković & Serb & Jugosłowiańska Wspólnota Radykalna & 3 II 1939-27 III 1941 \\
\hline
\end{tabular}

Źródło: opracowanie własne

62 M. Tanty, op. cit., s. 186; T. Szymczak, op. cit., s. 75.

63 Rozczarowani jugosłowiańskim rządem byli nie tylko Chorwaci czy Słoweńcy, ale również serbskie elity. Serbscy intelektualiści oskarżali głównie Chorwatów o zdradę jugosłowiańskiej idei, dla której Serbowie poświęcili swoją niezależność. Zob. J. Dragovic-Soso, Rethinking Yugoslavia: Serbian Intellectuals and the 'National Question' in Historical Perspective, "Contemporary European History" 2004, nr 13 (2), s. 174.

64 Sporazum Cvetković-Maček, 23. avgusta 1939, zob. B. Petranović, M. Zečević, op. cit., s. 476-478.

65 E. Bujwid-Kurek, Serbia w nowej przestrzeni ustrojowej, Kraków 2012, s. 37. 


\section{Podsumowanie}

Należy zaznaczyć, iż głównymi decydentami politycznymi zarówno w Królestwie SHS, jak i w Królestwie Jugosławii byli Serbowie. Monarchowie wywodzili się z serbskiej dynastii Karadjordjeviciów, natomiast fotel prezesa rady ministrów obejmowali serbscy politycy (z wyjątkiem Słoweńca A. Korošeca) ${ }^{66}$. Również reprezentacja parlamentarna przedstawiała się na korzyść Serbów. Polityka wewnętrzna i zagraniczna wyraźnie pokrywała się z serbskimi aspiracjami. Pomimo wieloetnicznego charakteru jugosłowiańskiego społeczeństwa pozostałe nacje nie miały wpływu na polityczny rozwój wydarzeń ${ }^{67}$. W ten sposób często określa się funkcjonującą w latach 1918-1941 jugosłowiańską państwowość jako „poszerzoną” Serbię ${ }^{68}$. Idea jugoslawizmu nie została w jednoznaczny sposób zdefiniowana i zaakceptowana przez Południowych Słowian. Dla Serbów oznaczała patriotyczne poczucie przynależności do wspólnego, powiększonego państwa ${ }^{69}$. W ten sposób serbski unitaryzm miał bezpośrednie przełożenie na autorytarną i centralistyczną politykę, której nie zaakceptowały pozostałe jugosłowiańskie narody. Z pewnością była to jedna z przyczyn radykalizowania się postaw zwłaszcza chorwackiej społeczności. Ostatecznie nierozwiązany problem podziału władzy doprowadził do zaostrzenia serbsko-chorwackiego antagonizmu podczas II wojny światowej. Królestwo Jugosławii zostało podbite przez wojska III Rzeszy w kwietniu 1941 roku. Na części ziem jugosłowiańskiej monarchii powołano Niezależne Państwo Chorwackie (1941-1945), w którym faszyzujący Chorwaci (Ustaše) bezwzględnie mordowali Serbów i inne nacje.

Przedstawiona w artykule analiza dziejów politycznych pierwszej Jugosławii potwierdziła stawiane tezy. Serbscy politycy zdominowali życie polityczne Królestwa SHS i Królestwa Jugosławii. Niedopuszczenie do władzy innych narodowości było bezpośrednią przyczyną słabości państwa. Konsekwencją był również permanentny spór serbsko-chorwacki, który podczas II wojny światowej przerodził się w otwarty konflikt.

66 W 1. 1918-1938 na 252 ministrów poszczególnych rządów aż 231 było Serbami, tylko 16 ministrów było Chorwatami i 5 Słoweńcami. I. Banac, op. cit., s. 217.

67 W 1. 30. wykorzystano hasłowy tytuł tekstu Vuka Karadžicia „Srbi svi i svuda” z 1849 r., nadając mu polityczne znaczenie. Рor. Ч. Попов, Велиика Србија. Стварност и мит, Нови Сад 2007, s. 260.

68 Badacze dziejów Jugosławii (1918-1941) wyróżnili kilka ustrojów politycznych jugosłowiańskiego państwa: lata 1918-1929 - quasi parlamentaryzm, lata 1929-1934 - dyktatura monarchy, lata 1934-1939 - państwo policyjne, lata 1939-1941 - serbsko-chorwackie kondominium. Zob. S. Ramet, Vladko Maček and the Croatian Peasant Defence in the Kingdom of Yugoslavia, „Contemporary European History" 2007, nr 16 (2), s. 216.

69 C. Job, Yugoslavia's Ruin: The Bloody Lessons of Nationalism, a Patriot's Warning, Maryland 2002, s. 13. 
Serbian political dominance in the first federation of South Slavic peoples - outline of issue

The article presents the issue of the Serbian hegemony over the political scene of first incarnation of Yugoslavia. The main assertion made is that the policies of Serbian decision-makers were a direct cause of the country's weakness. Moreover, Serbian political dominance sparked an internal ethnic conflict, with Croats in particular. The considerations begin with the characterisation of the Serbs' role during WWI and their influence on the establishment of the South Slavic federation. This is followed by the question of the political consolidation of the Serbian community within the Kingdom of Serbs, Croats and Slovenes, with focus on the functioning of national authorities, where the Serbs played a major role. Once an outline of the early political history of the kingdom (until its renaming in 1929) is drawn, the considerations move towards the subject of the rising political role of Serbs in the proper Kingdom of Yugoslavia. The article proceeds with an analysis of the behaviour of the Yugoslavian monarch and those politicians who endorsed the dictatorship, as well as the aftermath of this regime, namely the spiralling conflict between the Serbs and Croats over the political shape of the country. The analysis of the political history of the first incarnation of Yugoslavia presented in the article confirms its initial assertions. The Serbian politicians had dominated the political scene of the SCS Kingdom and Yugoslavia. The exclusion of other nations from power was the direct cause of the country's instability, and led to a permanent Serb-Croat dispute, which then turned into an open conflict during WWII.

Translated by Jakub Perliński

\section{Сербская политическое доминирование в первой федерации южнославянских народов (1918-1941) - очерк проблематики}

В статье представлен вопрос сербской политической гегемонии в первой Югославии. Основным тезисом статьи было утверждение, что политика сербских руководителей непосредственно влияла на внутреннюю слабость государства. Кроме того, сербское политическое доминирование привело к межнациональному конфликту, особенно с хорватами. Рассуждение начинается с описания роли сербов во время событий Первой мировой войны, а также их влияния на создание федерации южных славян. Затем обсуждается вопрос политического укрепления сербской нации в Королевстве Сербов, Хорватов и Словенцев.

Прежде всего автор отнесся к функционированию государственных властей, в которых основную роль играли сербы. Дан очерк политической истории Королевства вплоть до его переименования в 1929 г. В соответствии с хронологией событий, субъектом дальнейших рассуждений была растущая политическая роль сербов в Королевстве Югославия. Здесь был проведен анализ действий югославского монарха и политиков, которые санкционировали диктатуру. Затем автор отнесся к последствиям диктаторского правления в виде нарастающего сербско-хорватского спора о форму государственного устройства. Представленный в статье анализ политической истории первой Югославии подтвердил поставленные тезисы. Сербские политики преобладали в политической жизни Королевства СХС и Королевства Югославия. То, что к власти не допускались другие национальности являлось прямой причиной слабости государства. Одним из последствий был также перманентный сербско-хорватский спор, который во время Второй мировой войны преобразился в открытый конфликт.

Перевод Агнешка Поспишьль 


\section{Bibliografia}

Allock J. B., Explaining Yugoslavia, London 2000.

„Balcanica” XXXIX (2008), Annual of the Institute for Balkan Studies, red. D. Bataković, Belgrade 2009.

Balcerak W., Powstanie państw narodowych w Europie Środkowo-Wschodniej, Warszawa 1974.

Banac I., The National Question in Yugoslavia: Origins, History, Politics, Cornell University Press 1984.

Batowski H., Rozpad Austro-Węgier 1914-1918 (Sprawy narodowościowe i działania dyplomatyczne), Kraków 1982.

Бјелајац М., Дипломатија и војска. Србија и Југославија 1901-1999, Београд 2010.

Benson L., Jugosławia. Historia w zarysie, Kraków 2011.

Bujwid-Kurek E., Serbia w nowej przestrzeni ustrojowej, Kraków 2012.

Čulinovič F., Dokumenti o Jugoslaviji, Historijat od osnutka zajedničke države do danas, Zagreb 1968.

Djokic D., Nikola Pašić and Ante Trumbić. The Kingdom of Serbs, Croats and Slovenes, London 2010.

Đorđević M., Gudac Z., Savremena politika istorija Srbije, Crne Gore i SR Jugoslavije, Beograd 1995.

Draganich A. N., The First Yugoslavia: Search for a Viable Political System, Hoover Institution Press 1983.

Dragovic-Soso J., Rethinking Yugoslavia: Serbian Intellectuals and the 'National Question' in Historical Perspective, „Contemporary European History” 2004, nr 13 (2).

Drapac V., Constructing Yugoslavia. A transnational history, Basingstoke 2010.

Eberhardt P., Przemiany demograficzno-etniczne na obszarze Jugosławii w XX wieku, Lublin 2005.

Felczak W., Wasilewski T., Historia Jugosławii, Wrocław 1985.

Glenny M., The Balkans. Nationalism, War and the Great Powers 1804-1999, New York 2000.

Jelavich B., Historia Bałkanów. Wiek XX, Kraków 2005.

Job C., Yugoslavia's Ruin: The Bloody Lessons of Nationalism, a Patriot's Warning, Maryland 2002. Jović D., Yugoslavia. A State that Withered Away, Purdue University Press 2009.

Judah T., The Serbs. History, Myth and the Destruction of Yugoslavia, London 1997.

Kox J. K., The History of Serbia, Greenwood Press 2002.

Krkljuš L., Šarkić S., Odabrani izvori iz državnopravne istorije Jugoslavije, Beograd 1998.

Lampe J., Yugoslavia as History: Twice there was a country, Cambridge University Press 2000.

Malcolm N., Kosovo. A short history, London 1998.

Newman J. P., Post-imperial and Post-war Violence in the South Slav Lands, 1917-1923, „Contemporary European History" 2010, nr 19 (3).

Petranović B., Zečević M., Jugoslavija 1918-1988: tematska zbirka dokumenata, Beograd 1988.

Podhorodecki L., Jugosławia. Dzieje narodów, państw i rozpad federacji, Warszawa 2000.

Попов Ч., Велиика Србија. Стварност и мит, Нови Сад 2007.

Pułaski M., Z dziejów genezy Europy Wersalskiej. Współpraca Słowian zachodnich i południowych w ostatnim etapie I wojny światowej, Warszawa 1974.

Ramet S., Vladko Maček and the Croatian Peasant Defence in the Kingdom of Yugoslavia, „Contemporary European History" 2007, nr 16 (2).

Šišić F., Dokumenti o postanku Kraljevine Srba, Hrvata i Slovenaca 1914-1919, Zagreb 1920.

Skowronek J., Tanty M., Wasilewski T., Historia Słowian Południowych i Zachodnich, Warszawa 1988.

Skulic D., The creation and dissolution of the multinational state: the case of Yugoslavia, „Nations and Nationalism" 1997, nr 3 (2).

Slipičevič F., Istorija naroda Socijalističke Federativne Republike Jugoslavije. Novi Vijek, Sarajevo 1964.

Stranjaković D., Kako je postalo Garašaninovo „Načertanije”, Spomenik SKA, XCI, Beograd 1939. 
Szulc W., Przemiany gospodarcze i społeczne w Jugosławii w okresie międzywojennym 1918-1941, Poznań 1980.

Szymczak T., Jugosławia - państwo federacyjne, Łódź 1982.

Tanty M., Bałkany w XX wieku. Dzieje polityczne, Warszawa 2003.

Tomašević J., War and Revolution in Yugoslavia, 1941-1945: Occupation and Collaboration, Stanford University Press 2001.

Ustav Kraljevine Jugoslavije (Oktroisani ustav), Službene novine Kraljevine Jugoslavije, od 3. septembra 1931 godine.

Ustav Kraljevine Srba, Hrvata i Slovenaca, Službene novine Kraljevine SHS, od 28. juna 1921. godine. Yugoslavia through documents: from its creation to its dissolution, red. S. Trifunovska, Amsterdam 1994.

Walkiewicz W., Jugosławia. Państwa sukcesyjne, Warszawa 2009.

Wiktor Hebda - doktorant na Wydziale Studiów Politycznych i Międzynarodowych Uniwersytetu Jagiellońskiego, absolwent politologii i prawa karnego na Uniwersytecie Jagiellońskim oraz Akademii Młodych Dyplomatów w Europejskiej Akademii Dyplomacji w Warszawie, stypendysta na Uniwersytecie w Zagrzebiu, stażysta na Uniwersytecie w Belgradzie oraz w Państwowym Instytucie Spraw Międzynarodowych, laureat konkursu „Wiedza z pasją promujemy młodych naukowców", autor kilkudziesięciu artykułów naukowych i komentarzy. Zainteresowania naukowe: polityka i historia państw bałkańskich, bezpieczeństwo energetyczne (wiktor.hebda@uj.edu.pl). 